\title{
An Event Access on the Nascent Municipal Bond Market in India, Under a Seven-I Framework
}

\author{
Pali Gaur, Sundar Ram Korivi
}

\begin{abstract}
The objective of this paper is to trace the events in India from July 2013 until May 2015, and conduct an updated study on the opportunities and challenges presented by the issuance and trading of Munis in India. Such a study is intended to provide a comprehensive perspective for consideration by various stakeholders and policy makers in India. This is an event study using news analytics under the Seven-I framework (Issuers, Investors, Intermediaries, Instrument, Innovation, Incentives, Information) to provide specific insights to take the development of a Muni bond market forward. The latest development in the field of Munis in India is the release of SEBI Regulations for the listing and trading and the relevant disclosure norms. In parallel, SEBI is in close contact with the Ministry of Finance, Government of India for creating a policyframework for market-based funding of municipalities in India. Governance, Management and the Issuer's perspectives have been identified as the most-highlighted aspects from the data. However, SEBI and the Ministry of Finance also need to take note of the enveloping factors arising from the other Six Is, so that an enabling environment is created for a vibrant Muni bond market in India..
\end{abstract}

Keywords-Municipal Bonds, Muni, Munis, Indian Debt Market.

\section{INTRODUCTION}

\section{Background Context and Motivation}

Municipal Bond in India constitutes one among a set of six asset classes the Indian Debt Market. The set currently comprises of: (1) Central Government Bonds [G Sec] (2) State Government Securities [State G Sec] (3) Municipal Bonds (4) Corporate Bonds and (5) Infrastructure Bonds and (6) Securitized Debt [Asset Backed Securities = ABS and Mortgage Backed Securities = MBS $]$.

Municipal Bonds (also popularly known as 'Munis" the world over) possess at least six unique characteristics, placing them in-between State Governments and Corporations, as can be seen from Table 1. Municipalities are quasi-government entities, as they have the power to raise taxes and other imposts, comprising of members elected by the citizens. They are not commercial corporate bodies as they do not issue equity or shares, nor do they operate as 'for-profit' bodies. Investment and operating expenditures are funded by plough-backs from operational surpluses, government grants, taxes and other imports and loans or bonds. Munis represent the confluence between municipal finances and the capital markets.

Revised Manuscript Received on September 10, 2019.

Pali Gaur, Finance, IBMR, Gurgaon, Haryana India.

(E-mail: Pali.gaur@gmail.com)

Sundar Ram Korivi, Senior Cconsultant, DEA-NIFM Research cell at National Institute of Financial Management. Mumbai, Maharashtra, India.

(E-mail: sundfina9@gmail.com)
Of these six asset classes, G Sec, Corporate Bonds and Infrastructure Bonds have been listed on the stock exchanges. Till date, Municipal Bonds have been issued and redeemed in the private placement market. On December 30, 2014, Securities and Exchange Board of India (SEBI) released a concept paper on the issue and trading of Munis, for public discussion. The Ministry of Finance, Government of India, on January 3, 2015, invited recommendations from the Ministry of Urban Development for identifying five to six specific municipalities whose bonds could provide the promotional thrust for a vibrant Municipal Bond (Munis) market in India

[1].This was followed by the SEBI regulations on Munis on March 23, 2015. Since this asset class is receiving positive attention from the policy makers, it is likely to get a tax free status. In USA, Munis generally enjoy a tax-free income status, making them popular among retail investors and pension funds. Another source of support comes from the Indian insurance sector, which has a long history of investing in the Indian bond markets, including Munis [2].

In contrast to the positive signals emanating from the Central Government, SEBI and also the Insurance Regulatory Development Authority (IRDA), there are certain stakeholders in the Indian capital markets who are apprehensive about the success potential of Munis. Some of the challenges cited are: Lack of experience of municipal bodies in dealing with the investor community and servicing of investment, poor quality of accounting and management, poor financial condition, bureaucratic hurdles, political interference and lack of investor interest - to name a few.

The objective of this paper is to trace the events in India from July 2013 until May 2015, and conduct an updated study on the opportunities and challenges presented by the issuance and trading of Munis in India. Such a study is intended to provide a comprehensive perspective for consideration by various stakeholders and policy makers in India.

\section{Organization of Contents}

This paper is organized into 7 parts, as under.

1. Review of Literature

2. Research Design

3. Research Problem

4. Data

5. Methodology

6. Analysis, Findings and Discussion

7. Concluding Remarks 
Each of these bond classes has its own characteristics, as shown in Table I below.

Table- I: Asset Classes in the Indian Debt Market

\begin{tabular}{|c|c|c|c|c|c|c|}
\hline Bond Type & Safety & Liquidity & Yield & Maturity & Cash Flow & Tax Benefit \\
\hline $\begin{array}{l}\text { Central } \\
\text { G Sec }\end{array}$ & $\begin{array}{l}\text { Sovereign } \\
\text { (highest) }\end{array}$ & $\begin{array}{l}\text { High. Listed under } \\
\text { Wholesale Debt } \\
\text { Market (WDM). } \\
\text { All G Sec are not } \\
\text { liquid }\end{array}$ & Lower & $\begin{array}{l}29 \text { days to } \\
30 \text { years }\end{array}$ & $\begin{array}{l}\text { Zero-coupon to } \\
\text { coupon-bearing }\end{array}$ & $\begin{array}{l}\text { No with- } \\
\text { holding taxes }\end{array}$ \\
\hline State G Sec & $\begin{array}{l}\text { Lower than } \\
\text { sovereign. } \\
\text { Implicit Central } \\
\text { Government } \\
\text { guarantee }\end{array}$ & $\begin{array}{ll}\text { Lower } & \text { than } \\
\text { sovereign } & \end{array}$ & $\begin{array}{l}\text { Credit-risk } \\
\text { spread over } \\
\text { sovereign }\end{array}$ & $\begin{array}{l}91 \text { days to } \\
10 \text { years }\end{array}$ & Coupon interest & $\begin{array}{l}\text { No with- } \\
\text { holding taxes }\end{array}$ \\
\hline Municipal & $\begin{array}{l}\text { Implicit State } \\
\text { Government } \\
\text { guarantee; } \\
\text { Subject to } \\
\text { project risk, } \\
\text { escrow } \\
\text { mechanism }\end{array}$ & $\begin{array}{lr}\text { Low, } & \text { hitherto } \\
\text { unlisted. } & \text { Privately- } \\
\text { placed, } & \text { Held-to- } \\
\text { Maturity } & \text { (HTM) }\end{array}$ & $\begin{array}{l}\text { Higher than } \\
\text { sovereign }\end{array}$ & $\begin{array}{l}3 \text { to } 10 \\
\text { years }\end{array}$ & Coupon interest & $\begin{array}{l}\text { Nil. May } \\
\text { enjoy tax-free } \\
\text { status }\end{array}$ \\
\hline Corp Bond & $\begin{array}{l}\text { Riskier than G } \\
\text { Sec. AAA to D. } \\
\text { Subject to Cash } \\
\text { flows or credit } \\
\text { enhancement }\end{array}$ & $\begin{array}{l}\text { A few are listed; } \\
\text { trades are reported. } \\
\text { Mostly privately } \\
\text { placed, Held-to- } \\
\text { Maturity (HTM) }\end{array}$ & $\begin{array}{l}\text { Highest, } \\
\text { based on } \\
\text { credit-risk } \\
\text { spread }\end{array}$ & $\begin{array}{l}3 \text { to } 10 \\
\text { years }\end{array}$ & $\begin{array}{l}\text { Coupon interest. } \\
\text { Alternately, } \\
\text { cumulative } \\
\text { redemption plan }\end{array}$ & $\begin{array}{l}\text { Nil. } \\
\text { Withholding } \\
\text { taxes } \\
\text { applicable }\end{array}$ \\
\hline $\begin{array}{l}\text { Infra Bond } \\
\text { (Government } \\
\text { body or } \\
\text { stand-alone } \\
\text { corporate) }\end{array}$ & $\begin{array}{l}\text { AAA to D. } \\
\text { Subject to Cash } \\
\text { flows or credit } \\
\text { enhancement }\end{array}$ & $\begin{array}{lr}\text { Listed, } & \text { mostly } \\
\text { HTM. } & \text { Lock-in } \\
\text { period if } \quad \text { tax- } \\
\text { exempt }\end{array}$ & $\begin{array}{l}\text { Higher, } \\
\text { depending on } \\
\text { project risk, } \\
\text { credit } \\
\text { enhancement, } \\
\text { tax benefit } \\
\text { and tenor }\end{array}$ & $\begin{array}{l}10 \text { to } 15 \\
\text { years, lock- } \\
\text { in if tax } \\
\text { benefits } \\
\text { available }\end{array}$ & $\begin{array}{l}\text { Coupon interest. } \\
\text { Alternately, } \\
\text { cumulative } \\
\text { redemption plan }\end{array}$ & $\begin{array}{l}\text { Investment } \\
\text { benefit or } \\
\text { tax-free } \\
\text { income }\end{array}$ \\
\hline $\begin{array}{l}\text { ABS/MBS } \\
\text { (issued by } \\
\text { SPV) }\end{array}$ & $\begin{array}{l}\text { AAA to D. } \\
\text { Subject to Cash } \\
\text { flows or credit } \\
\text { enhancement }\end{array}$ & $\begin{array}{l}\text { Mostly privately } \\
\text { placed, Held-to- } \\
\text { Maturity (HTM) }\end{array}$ & $\begin{array}{l}\text { Depending } \\
\text { on credit } \\
\text { quality, } \\
\text { enhancement }\end{array}$ & $\begin{array}{l}3 \text { years to } \\
20 \text { years }\end{array}$ & $\begin{array}{l}\text { Graduated } \\
\text { repayment, } \\
\text { based on loan } \\
\text { originations }\end{array}$ & Nil \\
\hline
\end{tabular}

\section{REVIEW OF LITERATURE}

Considering the fact that three of the six types of bonds described in Table 1 emanate from the central, state and local government (Municipalities), their inter-relationship becomes important. Municipal finances are supported by government grants, loans or guarantees (explicit or implicit). State and local governments, faced with limited tax resources, will need to access funding in the form of loans or bonds, the latter being more liquid in nature. Such bonds case certain revenue streams are earmarked for bond repayments, such structures are called Revenue Bonds; in the absence of clearly earmarked revenue streams for the servicing of bonds, such bonds would be classified as General Obligation Bonds. Revenue Bonds generally enjoy higher credit ratings on account of the identified cash flow discipline, and supporting escrow mechanisms. In USA, pension funds and endowment funds invest a part of their funds in municipal bonds, and credit ratings play a large part in influencing these decisions.

In the field of Public Economics, The Flypaper Effect is a classic paper by Hines and Thaler (1995) outlining the financial behavior of municipalities. It highlights the tendencies of municipalities to continue raising local tax will need to be serviced through revenues or reissuances. In streams from incremental revenues, the attendant financial

revenues even when financial grants flow in from the state and central governments. As a result, Central and State government grants intended for the benefit of the common citizens do not percolate through municipal bodies. In other words, the Flypaper Effect observes that 'money sticks where it hits'. Other papers in the same genre, describing the Relationship between government bodies inter se are (in chronological order) by Hines, Hoynes and Krueger (2001), Temimi and Dix (2001), Knight (2002), Timofeev (2002), and by Buettner and Wildasin (2003). The aforementioned papers by Timofeev and Buettner et al focus on the Russian/CIS and German local bodies. All other papers are based on US experiences. An undated paper by Roemer and

Sylvestre confirms the findings of Hines and Thaler. All of these works ranged from 1995 to 2003.

In the field of Financial Economics, a paper by Wang, $\mathrm{Wu}$ and Zhang (2008) focused on the role of liquidity on the shape of the yield curve relative to the Treasury yield curve, and found liquidity to have a significant explanatory role. Since it was based on a transaction database on US markets, a detailed empirical study was feasible. Papers cited by 
Wang et al (2008) are on yield curves, default rates and credit risk. The Indian debt markets have not yet reached such stages of depth and sophistication, and there is no data to replicate this type of empirical work at this stage.

In addition to the papers cited above, two seminal books touching upon the subject of public finance and municipal bonds are discussed below.

In the field of Financial Economics, a book by Megginson 'The Privatization of Financial Economics' (2005), highlighted the manner and sequencing of process to best achieve privatization. It advised against privatization of water and sewerage services, implying that such services continue remain with the government or local government.

In the field of Financial Market Regulation, a highly detailed account on the financial condition of municipal bodies and local authorities in the US, is documented by Partnoy in his 2003 book, titled 'Infectious Greed: How Deceit and Risk Corrupted the Financial Market'. Importantly, this work pre-dated the Global Financial Crisis (GFC) of 2008 and was prescient in many respects: on how greed on the part of market participants adversely impacts financial markets and, in particular, ruined the reputation of municipalities and local bodies in US. This piece of work makes an excellent case study, as summarized in the paragraphs below.

Robert Citron was the head of treasury of Orange County (California) for several years. The balance sheet of Orange County consisted of both, bond issuances (liability side) and investment in fixed income securities (asset side). Over the years, Citron got comfortable with buying structured notes (fixed income products) from Merrill Lynch and other investment bankers. Such instruments were carved out of the cash collaterals from an underlying loan portfolio, and were rated AAA, based on the balance sheet strength of the noteissuing investment bank. One such investment was the inverse floater, which gained when interest rates fell. On the liability side, Citron got Orange County bonds issued for shorter tenors, in contrast to the structured inverse floaters which were of a longer maturity. The net-interest income play was based on the premise that interest rates would remain low, keeping borrowing costs low and investment prices high. However, when interest rates were actually raised from $3.00 \%$ to $3.25 \%$, the bets came unstuck: short term borrowing costs rose, inverse floaters earned a lower coupon, and the entire fixed income portfolio took a capital loss. Other market borrowings by Orange County came in for margin calls, as the collateral values declined. Orange County was unable to repay its bondholders and filed for bankruptcy in 1994. Investors in Orange County bonds who were adversely impacted included many conservative funds such as Alliance Capital, Dean Witter, Putnam Management and Franklin Templeton, apart from thousands of residents of Orange County.

Three lessons from this episode are:

Governance: Orange County relied entirely on Robert Citron's judgment, and he took on excessive risk. There were no limits placed on the market exposures that he took. It is a textbook case of overexposure by a single trader, giving credence to the concept of Value-at-Risk ( $\mathrm{VaR}$ ).
Conflicts of Interest: Merrill Lynch, which sold structured financial instruments to Orange County, was also the investment bank for the bond issuances of Orange County. The offer documents of Orange County bonds did not reveal the risky structured finance investments. Likewise, the credit rating agency $(\mathrm{S} \& \mathrm{P})$ which rated the asset side instruments, also rated the liability side instruments. The offer document also did not reveal that the investment side represented disguised derivative instruments (inverse floaters), carved out of loans which were the true underlying assets. Bonds designed by Citron and S \& P stamped the securities with a higher rating. In fact, the International Swaps \& Derivatives Association (ISDA) discouraged attempts by investment banks, rating agencies and the media from calling inverse floater notes as derivatives.

Jurisdiction: SEC had a jurisdiction over the bonds issued by municipalities but not over the investments made by them using taxpayers' monies, in unlisted structured financial instruments based on bank loan originations..

The damage was widespread. Out of 31 public bodies mentioned in various investigative reports, 28 that were adversely impact in a manner similar to Orange County were:

$\begin{array}{ll}\text { - } & \text { Charles County, Maryland } \\ \text { - } & \text { City Colleges of Chicago } \\ \text { - } & \text { Eastern Shoshone Tribe, Wyoming } \\ \text { - } & \text { Escambia County, Florida } \\ \text { - } & \text { Lewis \& Clarke County, Montana } \\ \text { - } & \text { Municipal Electric Authority of Georgia-Auburn, } \\ \text { Maine } & \\ \text { - } & \text { Odessa College, Texas } \\ \text { - } & \text { Ohio Municipalities (18 of them) } \\ \text { - } & \text { San Diego County } \\ \text { - } & \text { Sarasota-Manatee Airport Authority } \\ \text { Prudence and conservatism prevailed in a few places, like }\end{array}$

Prudence and conservatism prevailed in a few places, like Farmers' Branch (Texas) and Alabama State Pension Fund, where the investment managers said that they were prudent enough not to be drawn into instruments that they did not understand.

There is some Indian literature on the subject. Vaidya and Vaidya (2010) highlight the importance of bonds for supplementing grant financing. The judicious use of PPPs will also bring in equity finance. This calls for the identification of financially viable projects. Chakrabarti (2014) researched on the ratings of Munis in India. Hence, there is a need for incentivizing investors in this sector, particularly insurers, pension funds, banks and other constituencies, with tax benefits. Financial sector regulators may also include such bonds under the priority sector or approved securities.

The papers and books reviewed thus far provide the following insights:

1. The literature available is from 1995 to 2008

2. The market for Munis is well-established in USA

3. There is enough data for empirical research on pricing, liquidity, credit and default risk etc. 
4. Municipal bodies are generally well-managed, barring the ones cited by PartnoyThere are municipal bodies wherein financial misadventures have led to financial and operational failure

5. Aspects such as governance, conflict of interest, financial regulatory jurisdiction need to be identified addressed

In the context of this paper, the following gaps arise:

1. Data, reports and work in the post-2008 era need to be studied, particularly post SEBI Regulations for listing and disclosures in respect of Munis in India.

2. In the absence of a transactional database, all extant and available data or information needs to be collated for analysis

3. A template or roadmap is required for the Indian Muni bond market to emulate

4. The successes and pitfalls need to be listed coherently, for incorporation into future action plans

\section{RESEARCH DESIGN}

From personal interactions by the authors with Jefferies (2010), the following information is culled out:

Jefferies is a leading, independent, full-service investment bank in USA. It has a vibrant Municipal Securities Group. On July 16, 2010, Jefferies made a presentation to the Mumbai Stock Exchange on the market for Munis in USA. Salient features are summarized as under:

Most of the bond issuances are tax-free and long-term in nature. In terms of primary market volumes, revenue bonds account for around $30 \%$, whereas general obligation bonds account for $70 \%$.

The major activities funded by Munis are: Utilities, Transportation, Healthcare and Education. The major investors in are: Households (35\%), Mutual Funds (17\%), Insurance Companies (16\%), Money Market Funds (14\%), Commercial Banks (8\%) - all of the aforesaid account for almost $90 \%$ of the holdings.

The Research Design comprises of:

- Enunciation of the Research Problem

- The Data that can be subjected to analysis

- Analytical techniques for arriving at a policy template

\section{RESEARCH PROBLEM}

The insight from Jefferies serves as a rough directional template for the Indian Muni bonds market to evolve. The input from Jefferies becomes all the more significant because secondary market trade data in India is non-existent to perform the type of empirical research by Wang et al (2008).

Four of India's largest credit rating agencies have, at some point, conducted studies on the market for Munis. ICRA's 2008 study mentioned that most the 13 issuances were of investment grade, and there is scope for improvement if issuers improve their practices. Policymakers need to address aspects pertaining to market structure. CRISIL's 2011 study calls for accounting disciple if market-based financing is to be accessed. CARE's 2012 study identifies the need for a diversified fund base, in order to achieve rapid urbanization. Pooled financing is also suggested. Policy-makers need to look at balancing the supply and demand side for Munis. CARE's 2014 study suggests incentives for issuers and investors, and also for a body to issue bonds for on-lending to municipalities. The most recent study is by India Ratings in 2015, which estimates the market for Munis in India at over US\$ 7 billion. It also suggested a pooling of issues, with government incentives to the citizenry for participation in the bonds. Specialized entities may also issue pooled bonds, as suggested by the study.

The latest development in the field of Munis in India is the release of SEBI Regulations for the listing and trading and the relevant disclosure norms. In parallel, SEBI is in close contact with the Ministry of Finance, Government of India for creating a policy-framework for market-based funding of municipalities in India.

The key research questions that arise are:

1. What are the governance and managerial aspects that municipalities need to work on and improve?

2. In what manner do the various stakeholders contribute to the development of a market for Munis in India and what are the enabling factors, as perceived by the stakeholders?

\section{DATA}

In order to keep the paper in tune with the contemporary developments, particularly the period surrounding the announcement of the SEBI Regulations for the listing, trading and disclosure of Munis in India, the news analytics technique (Mitra and Mitra) was deployed for this paper. Information flows in the form of news reports, from the period July 2013 through May 2015 (i.e. 23 months) were available. This represented unstructured data. This was converted into structured information in an EXCEL spreadsheet. 36 observations were available, which were converted into nine fields in respect of each news item Further details are discussed in the Methodology section below.

\section{METHODOLOGY}

This paper is essentially in the nature of an event study on episodes concerned with the Muni bond market in India, over a 23-mont period.

In one of the most recent and pioneering development in the field of Finance, Mitra and Mitra (2011) demonstrate how financial sentiment can be culled out from news feeds Academic papers have shown that useful information can be extracted through news analytics. Such social statistics enable researchers to define and measure phenomena in society and quantify the forces which steer markets.

The first set of fields consists of two aspects, Governance and Management. The second set of fields consists of seven aspects: Issuers, Investors, Intermediaries, Instruments, Innovations, Incentives and Information. This 7-I framework is the one that the Reserve Bank of India (RBI) follows as a template to design systems for a corporate bond market in India.

Against each of these nine aspects, a 1 or 0 is marked, in respect of each of the 36 news

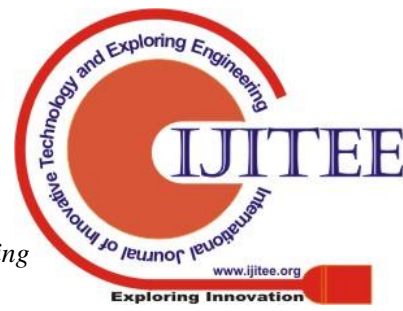


items. This digitizes the EXCEL data and captures public opinion on each of the aspects. In this manner, unstructured data becomes information, which, when analyzed, could provide useful insight.

The analysis is then collated to cull out action points for policy-makers and stakeholders.

\section{ANALYSIS, FINDINGS AND DISCUSSION \& RESULTS}

To reiterate, a total of 36 observations were available for news analysis, ranging from the period July 2013 until May 2015 , covering 23 months. Of these 36 observations, only 1 was from 2013, 20 were from 2014 and 15 were from 2015 (first half). Within 2014, there was no activity until May 2014. The intensity of news flow was from June 2014 to May 2015, i.e. the latest one year was the most active, with a total of 35 observations, on average, 3 per month.

The general perception of municipal bodies in India is that of poor governance and management practices. In order to obtain specific points of insight, the 36 news items have been parsed under two heads: Governance and Management. Governance refers to ethics and ethos, whereas Management refers to efficiency of functioning. The two are not without overlaps. Significantly, 14 of the news items cover Governance and 28 items cover Management aspects. These aspects are discussed below.

News items began to express opinions on Governance and Managerial aspects with greater intensity from July 2014 onwards. Points 1 or 0 were assigned to a news comment on either aspect.

These are captured in Figure 1 below.

Figure 1: News Items Covering Governance \& Management Aspects

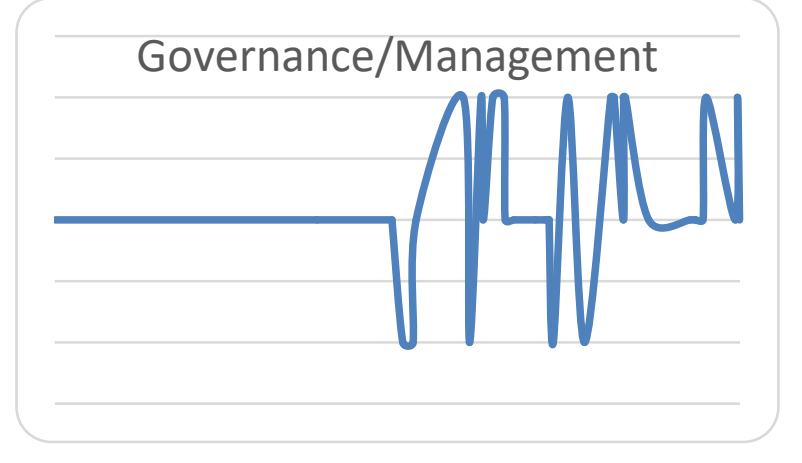

Figure 1 above describes the increasing intensity of discussion on governance and managerial aspects. A detailed discussion on these aspects is carried below.

\section{A. Governance Aspects}

The 2014 survey by NGO Janagraha placed great emphasis on democratic and participative processes. Kolkata ranked at the top, since the mayor is an elected representative of the people, unlike Mumbai, where the mayor is an unelected political appointee and hence, has no accountability.

Thiruvananthapuram ranks high on account of the appointment of an ombudsman to hear and settle citizens' grievances. This lack of accountability has led to poor governance systems. A case in point is the New Delhi
Municipal Council (NDMC) that originally governed Lutyen's Delhi, which was dissolved in September 2014 due to its abject failure to perform. The Union Minister for Urban Housing and Poverty Alleviation, Government of India had termed the condition of Indian municipalities as a mess, and ill-equipped to meet the challenges arising from citizens' expectations.

Relationships of the municipalities with the State and Central Government play a major role in their functioning. Municipalities are generally not free from political interference. The Municipal Corporation of Delhi (MCD) was trifurcated into East Delhi Municipal Corporation (EDMC), South Delhi Municipal Corporation (SDMC) and South-West Delhi Municipal Corporation (SDMC). As a consequence, EDMC, which mainly has slums areas under its jurisdiction, lost the affluent areas which are potentially property-tax zones to the other two municipal jurisdictions. EDMC has gone into a perennial deficit. This demonstrates that decentralization with an intention of better governance could backfire if the economies of scale arising from centralization are cut off abruptly. Hence, a right mix of centralization and decentralization are called for. In the case of Mumbai, the total apathy arising from unelected bureaucrats and officials has led to under-utilization of funds.

\section{B. Managerial Aspects}

From news reports in 2013, the case of Detroit revealed another stark reality of dwindling tax revenues. Detroit's decline was synonymous with that of its once-famed automobile industry. Competition from global automobile makers rendered Detroit's industry unviable on cost competitiveness, leading to mass closures. This case reflects the dangers of overdependence on a single industry, which could potentially lead to a complete shutdown in economic activity, declining tax revenues and subsequently, the inability to service bondholders. Detroit filed for bankruptcy. This is a call for revenue diversification. Other bankruptcy cases are Jefferson County (Alabama), Stockton, San Bernadino and Vallejo - all from California.

The 34 US cases cited in this paper expose the vulnerability of Munis to financial shock and mismanagement. On the flip side, there are several wellmanaged Municipalities whose bonds continue to enjoy the trust of investors. The tax-free nature of Munis adds to their allure [3].

Failures of certain municipalities in US, particularly Detroit (Michigan), Jefferson County (Alabama), Stockton, San Bernadino and Vallejo - all from California, have been discussed earlier. These are managerial failures that subsequently turned into financial failures.

One major change that is likely to occur in the state of Maharashtra is the abolition of the Local Body Tax (LBT), even as the state mulls over other sources of revenue such as a purchase tax (that could be counter-productive). Alternately, the fee in respect of additional Floor Space Index (FSI) [i.e. the ratio of a building's permitted floor height to its land area for construction] could be raised.

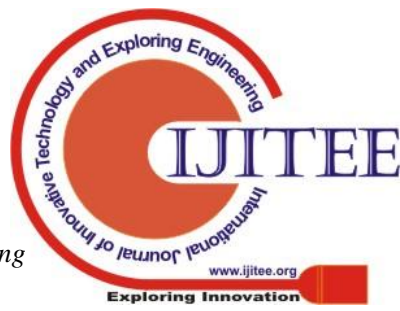


Such revenue constraints could drive up the demand for financing through bonds, which is a migration from a Public Economics solution to the capital market solution calling for better planning and design systems, resourcing systems, and also accountability and transparency systems to attract investors.

A Deloitte study has indicated that although Public Private Partnerships (PPPs) are the way ahead, there will be no improvement in accountability or performance of projects if the Public Sector (i.e. the municipal bodies) have a low accountability.

Revenue shrinkages, as the EDMC example demonstrates, could lead to a deterioration in finances. In the case of Mumbai, prolonged spells of labour unrest led to the flight of its textile industry to Gujarat. West Bengal could face the same situation since labour is highly unionized.

The coinage and concept of the term 'smart cities' has reinvigorated the discourse on planned urbanization. 15 new metropolitan cities and 12 affluent non-metros are the emerging cities to watch out for in 2025 as per McKinsey Global Institute (MGI). Demarcation of revenue streams could make potential bond issues a success, particularly with a nouveau middle class emerging as consumers-cuminvestors.

From a managerial approach, municipalities need to move away from the form and functioning as quasi-government bodies and align themselves as corporate bodies. From a Corporate Law and Corporate Finance perspective, municipalities that issue bonds will need to plan their redemptions through generation of revenue surpluses and other resources. They also need to develop relations with bond trustees who represent investors' interests and inculcate the right culture to deal with the investor community, especially on matters relating to Finance \& Accounts.

SEBI's stipulation of revenue bonds as a pre-condition for listing instills a sense of financial discipline in the management of finances of a municipality. Specific revenue streams arise from earmarked income-generating activities. This could be based on a market-oriented and citizenfriendly assessment of civic services. The necessary infrastructure would thus be self-financing in nature.

Put together, the Governance and Managerial aspects point towards a strong CEO and CFO culture, blended with participative processes at the Mayoral level, an Ombudsman level and a consumer-centric approach, with short- medium and long-term planning. It is a blend of participative democracy with the attendant accountability, and corporatestyle efficiency. Across all levels of management and governance, there is a felt need for specific training inputs.

\section{THE SEVEN-I FRAMEWORK}

These 36 observations were placed under the Seven-I framework devised by the Reserve Bank of India to study the corporate bond market. It comprises of the following seven aspects:

$\begin{array}{ll}\text { 1. } & \text { Issuer } \\ \text { 2. } & \text { Investor } \\ \text { 3. } & \text { Intermediary } \\ \text { 4. } & \text { Instrument }\end{array}$

\section{Innovation \\ 6. Incentive \\ 7. Information}

Tabulated below are the number of news items against each aspect.

Table 2: No. of News Items Against Each Seven-I Aspect

\begin{tabular}{|c|c|c|}
\hline S No & Aspect & No. of News Items \\
\hline 1 & Issuer & 24 \\
\hline 2 & Investor & 6 \\
\hline 3 & Intermediary & 5 \\
\hline 4 & Instrument & 7 \\
\hline 5 & Innovation & 4 \\
\hline 6 & Incentive & 3 \\
\hline 7 & Information & 3 \\
\hline
\end{tabular}

In all, there are 52 impact points across the 36 observations, as the same news item could simultaneously impact more than one aspect.

It can be seen that most of the news items cover the Issuers. Investors, Intermediaries and Instruments each find equal mention, although at $1 / 4^{\text {th }}$ the intensity as compared to Issuer, and the following three: Innovation, Inventive and Information each have only $1 / 6^{\text {th }}$ the intensity as compared to Issuer. The analysis and discussion that follow carry salient aspects on each of the aspects.

When the impact ( 1 or 0 ) of each news event against each aspect was totaled, the following graph emerged (See Figure 2 below)

Figure 2: News Opinion on the 7-I Aspects

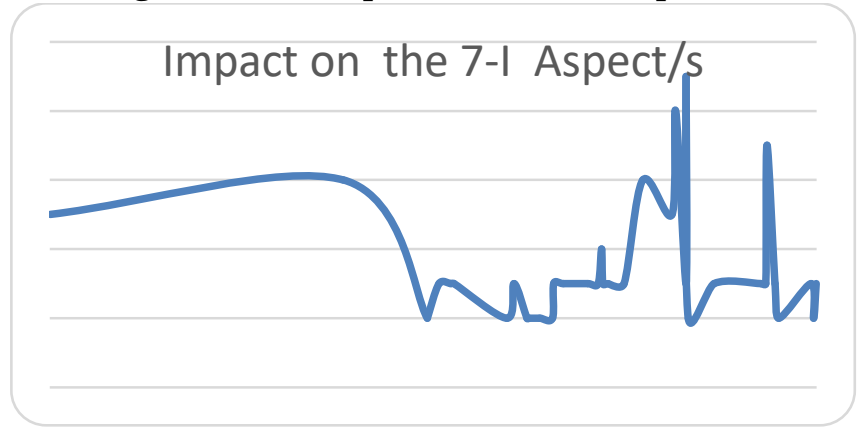

The figure describes the rapid pace of announcements from November 2014 to March 2015, followed by a lull. SEBI's discussion paper of December 2014 inviting public opinion created a spike in activity, followed by more announcements in January 2015 and the final SEBI regulations in March 2015. From then on, at the end of Financial Year April 2014-March 2015 and the beginning of Financial Year March 2015-March 2016, it is back to the drawing board for all stakeholders, and the next positive, perhaps, could be tax-free status for Munis.

\section{A. Issuer}

There have been only 25 issues of Munis by 8 cities in the past 17 years. These are listed below:
1. Ahmedabad
2. Nagpur
3. Nashik
4. Ludhiana 


$\begin{array}{ll}\text { 5. } & \text { Tamil Nadu } \\ \text { 6. } & \text { Bangalore } \\ \text { 7. } & \text { Indore } \\ \text { 8. } & \text { Madurai }\end{array}$

As existing tax revenue streams dry up, municipalities will be forced to look for alternative sources of revenue and funds. In the case of the Municipal Corporation of Delhi (MCD), GIS mapping of locations was suggested by the central government, to keep a tab on encroachments, and therefore, potential declines in property taxes. Consulting firm Deloitte had observed that funding will be a major challenge for municipalities, and therefore, PPPs will have a major role to play in creating urban infrastructure. However, municipalities need to approach PPPs from a position of strength, besides good governance and management, or else, inefficiencies and corruption will rise.

In China, as was the case in Detroit, ghost towns and deserted towns witness shrinkages in their revenue bases, weakening the case for servicing bonds. Poor finances and financial management deter investors. Population trends may change over the decades, as new cities and towns spring up, without legacy problems. Around 15 new metropolitan cities and 12 affluent non-metros, totaling to 27 cities will rise by 2025 , according to a study by MGI. New cities will drive up the demand for automobiles and other goods and services, raising the revenue base in terms of taxes or user-charges. It is imperative for cities to tap revenue streams in order to service muni bond obligations. There are potentially over 7985 cities across more than 640 districts, spanning 27 states and 7 union territories, demonstrating the staggering diversity and heterogeneity in India, according to another study by MGI.

SEBI floated a discussion paper on Muni bonds in December 2014, and followed up with norms for issuers and listing, in March 2015, raising the tempo for a Muni bond culture in India. The Ministry of Finance, Government of India, also sought the identification of five to six cities whose Munis could be raised, to kick-start a Muni bond culture in India. Experts opine that market-based planning by municipalities will help them align with investorexpectations.

Municipal bodies in Maharashtra state are keen on raising revenues from fees on increased Floor Space Index (FSI), a kind of property-related revenue. Revenues from tourismrelated services are also being keenly considered by the Maharashtra government. In Delhi, the trifurcation of the large (erstwhile) of MCD has resulted in a lop-sided revenue pattern, the biggest sufferer being EDMC, which mainly has slums in its jurisdiction, whereas the property-tax yielding areas have ceded to other municipal bodies. Thus, ad-hoc decentralization does not help. What is required, therefore, is a right mix of centralization and decentralization. Another precious resource is water; mispricing of water leads to distortion in its usage and revenue losses. Finally, as big industrial houses move out of big cities into smaller ones, the service sector and the unorganized sector becomes the major revenue-earner in the older cities. Suitable infrastructure such as transport, electricity, hospitals, education, water and sewerage need to be developed to support service-oriented businesses, so that they emerge as revenue streams.

It is reiterated here that many or most of the demand for municipal services is inelastic, and that the civic bodies enjoy natural monopolies. In the absence of funding for infrastructure, the subsidy model could be partly replaced by a user-pays model, where there is potential for PPPs. With imaginatively planned land-use projects, captive land under the charge of municipalities could even be effectively monetized through infrastructure services. Private sector investment could come in for resources other than land.

Finally, based on the extant Indian experience, the potential services and opportunities for generating revenues are tabulated as under.

Table 3: Revenue Matrix

\begin{tabular}{|l|l|l|l|l|}
\hline Revenue Stream & Subsidy & User Pays & PPP & Tax \\
\hline Water & Yes & Yes & No & No \\
\hline Sewerage & Yes & No & No & Yes \\
\hline Transport & Yes & Yes & No & No \\
\hline Roads & Yes & Yes & Yes & No \\
\hline Hospitals & Yes & Yes & No & No \\
\hline Schools & Yes & Yes & No & No \\
\hline Waste & Yes & No & Yes & Yes \\
\hline
\end{tabular}

According to Megginson (2005), privatization of water and sewerage, being public goods, should be the last option for the government, and should stay with the government for as long as possible. This opens up revenue streams for the local governments, by metering water usage for billing, and user-charges on commercial units for sewerage disposal.

This revenue matrix could undergo changes over time. For instance, the case for metering of water usage is getting stronger by the day. Road projects are toll-able, but have met with resistance from citizens, especially in Maharashtra, rendering PPPs unviable. Schools and hospitals have potential to generate revenue, if well managed.

\section{B. Investor}

In developed countries, household savings are the main investor base for Muni bonds. A major contribution from SEBI's regulation is the earmarking of revenue streams to protect investor interests, together with listing and disclosure norms. Listing brings in the feature of liquidity, but actual liquidity would depend on the interaction between various classes of investors. Any cap on interest rates would be a dampener. Tax-free interest, as is the global trend, would attract individual investors, whereas the larger players, i.e. institutional investors, would require marketdetermined interest rates. The success of tax-free bonds by several Indian infrastructure providers such as the National Highway Authority (NHAI), Indian Railway Finance Corporation (IRFC) and others, totaling to approx. US\$ 6 billion per annum, which was oversubscribed 5 times by individual investors. Investors will also expect better relationship management from the issuers' side. Potential investors in Munis as an asset class are individuals and households, insurance companies, pension funds, 
debt mutual funds and probably banks.

\section{Intermediaries}

The SEBI norms on the issuance, listing and trading of municipal bonds give rise to a whole set of intermediaries that function in the securities markets. Some key functions are listed below.

Table 4: Potential Roles for Intermediaries

\begin{tabular}{|c|c|}
\hline Intermediary & Nature of Intermediation \\
\hline $\begin{array}{l}\text { Accounting } \\
\text { and Audit } \\
\text { Professionals }\end{array}$ & $\begin{array}{l}\text { The first gatekeeper. Setting up accounting } \\
\text { systems, Management Information Systems } \\
\text { (MIS), a dherence to standards of disclosure, } \\
\text { inculcating good govemance and } \\
\text { management practices }\end{array}$ \\
\hline $\begin{array}{l}\text { Investment } \\
\text { Banker }\end{array}$ & $\begin{array}{l}\text { Advisory, Consultancy and preparing } \\
\text { Municipalities for public issuance of } \\
\text { securities, facilitating the private placements } \\
\text { and public offerings, taking care of pre-and } \\
\text { post-listing activities, liaison with credit } \\
\text { rating agencies. Also plays the role of key } \\
\text { underwriter and market maker }\end{array}$ \\
\hline $\begin{array}{l}\text { Credit Rating } \\
\text { Agencies }\end{array}$ & $\begin{array}{l}\text { The second gatekeeper. Scrutiny of cash } \\
\text { flows, due diligence review and rating of } \\
\text { securities }\end{array}$ \\
\hline Underwriters & $\begin{array}{l}\text { Placement of securities and securing the } \\
\text { issuance of securities. May also play the role } \\
\text { of a market maker in the post-listing phase }\end{array}$ \\
\hline $\begin{array}{c}\text { Stock } \\
\text { Exchanges }\end{array}$ & $\begin{array}{l}\text { Regulate the allotment, listing and trading, } \\
\text { takes care of disclosure norms, provides the } \\
\text { infrastructure for the price discovery process }\end{array}$ \\
\hline Stock Brokers & Accepting and executing of orders \\
\hline $\begin{array}{l}\text { Trustees to } \\
\text { Bondholders }\end{array}$ & $\begin{array}{l}\text { Safeguard the investors, examine collateral } \\
\text { security, reduce asymmetric information, } \\
\text { maintain investor-investee relations }\end{array}$ \\
\hline $\begin{array}{l}\text { Market- } \\
\text { makers }\end{array}$ & $\begin{array}{l}\text { Provide liquidity via two-way quotes until } \\
\text { issues are sold down }\end{array}$ \\
\hline $\begin{array}{c}\text { Credit } \\
\text { Enhancers }\end{array}$ & $\begin{array}{l}\text { Credit insurance for capital market } \\
\text { instruments is at a very nascent stage in } \\
\text { India, although Credit Default Swap } \\
\text { guidelines have been in place since over two } \\
\text { years. }\end{array}$ \\
\hline
\end{tabular}

One of the observations clearly reveals that market makers will be crucial in the success of secondary trading. In the Indian corporate bond market, there are six to seven intermediaries who bridge the timing gap between the supply of securities and the demand for securities.

\section{Instrument}

Several notable features have been highlighted in the data. First and foremost, the bonds are to be based on clearly identifiable revenue streams. Coupon interest on bonds may be tax-free or taxable. Listing provides opportunities for liquidity and continuous price discovery, supplemented by market-making, wherever feasible. As per SEBI regulations, the minimum tenor must be of 3 years.

At this nascent stage of development in the Indian debt markets, it may be advisable for the bonds to be plainvanilla, coupon-bearing instruments. Innovations could come in the forms of tax incentives, listing and credit enhancements. Call option features embedded by issuers could be a dampener for investors.

\section{E. Innovation}

The Tamil Nadu state government pooled together the funding requirements of certain municipalities and issued a single bond. Such pooled bonds were issued in India for the first time and only time. It generates a critical mass in terms of issue size, and also carries a credit enhancement feature in the form of an implicit guarantee of the state government of Tamil Nadu, to bring in investor confidence. Considering the staggering diversity in the size and spread of cities that can potentially issue bonds, the pooled bond solution seems to be the best alternative for reducing this diversity.

As is the case in developed countries, there is a need to bring in retail participation into Munis. The success of taxfree bonds by national public sector entities such as National Highway Authority (NHAI), National Bank for Agricultural and Rural Development (NABARD), Indian Railway Finance Corporation (IRFC), Power Finance Corporation (PFC) etc., underscore their popularity amongst the investing community.

Amounts up to US\$ 6 billion had been raised through taxfee public sector bonds, showing the investor appetite, in case the yields are perceived as attractive [5]. Institutional investors may not need the tax-free status, but seek safety through higher ratings and credit enhancements. Withholding taxes on coupon interest could also impede liquidity in the secondary markets. Listing would be a benefit that could impart liquidity and hence, result in a reduction in the expected yield, bringing cost of funds down for the issuing municipalities.

In order to save issuance marketing costs, municipalities could come up with a common offer document consisting of tax-free and taxable bonds.

There could be a case for new municipalities being structured as non-profit corporations, and bring them under the purview of say, Section 8 of the Indian Companies Act, 2015. Such a step had been mulled over by the SEBI. This brings in the relevant clauses of creating redemption reserves and trustees to safeguard the investors' interests and observance of covenants.

\section{F. Incentives}

The incentive for the issuer would be lower cost of funds, as tax-free bonds would be a non-zero sum games, as per the USA experience. This is because, the investor (mostly high net-worth individuals) would be willing to settle for a lower coupon rate, whereas the municipality would get the interest payment as tax-deductible. A lower coupon rate would also be justified by liquidity arising from listing, i.e. to reverse illiquidity premium in the coupon interest. Credit enhancements could bring in further economies for the issuer, investor and the enhancement provider in case risks are assessed and managed in a professional manner. In China, loans given by banks to local governments for building huge investments went bad when revenues failed to fructify, potentially crippling the banking system. This makes a case for Muni bonds, where issuances are subject to market scrutiny and also result in diversified holdings, so as not to cripple a bank or banks, as happens in a loan-oriented system. A distinct advantage of municipalities is the natural

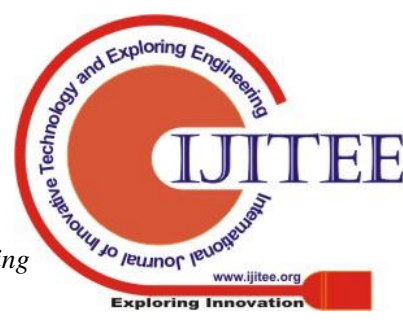


commercial monopoly they enjoy on certain services such as water and sewerage treatment. Such monopoly power is likely to translate into higher ratings, attract investors.

In case Munis do take off successfully as an asset class, a whole new community of intermediaries would see a kickstart in their business, commencing from investment banks, credit enhancers, market makers, credit rating agencies, accountants and auditors, information \& analytics firms, legal professionals, trustees, stock exchanges, stock-brokers, depositories etc. For the government, there are stamp duties to be earned on the creation of new financial instruments.

It is necessary for regulators and policy-makers to address the aspect of conflicts in interest, as evident from the Orange County case, while examining the various incentives in the financial markets.

\section{G. Information}

Information is the most essential ingredient of financial markets, in addition to funds. The gate-keeping function in the financial market is performed by the internal management, accountants, auditors, credit rating agencies, investment bankers, stock exchanges and regulators. Investors need to be protected from the ills of asymmetric information. Although all types of information are inherently asymmetric, they need to be minimized, which is a critical function of regulators and policy-makers.

Information is known to be a weak point of Indian municipal bodies, which lack transparency. In fact, even according to the Institute of Chartered Accountants of India, may municipalities follow the single entry book keeping method, with archaic and entrenched bureaucratic processes. Public issuances of bonds and listings will enforce market discipline on the municipalities.

\section{CONCLUDING REMARKS}

Literature suggests that the Flypaper Effect is a real-life phenomenon, and government grants are not likely to percolate to the citizenry, in most cases. Fiscal stress in the central and state governments will create fund constraints and drive municipalities towards market-oriented finance. Lessons from the Orange County case, on governance, conflicts of interest and regulatory jurisdiction need to be borne in mind when designing policy frameworks, with the attendant checks and balances. The Detroit case underscores the ill-effect of a shrinking revenue base, highlighting the need for a diversified revenue base.

Overall, tax-free status of bonds is an important incentive for individuals and householders - a key investor class.

This paper attempts to look at the post-2014 scenario empirically through event studies, and its conclusions are based on observations up to May 2015. Governance and Managerial aspects are reviewed with the intent to gain specific insights. For more specific insights on how to operationalize the development of a Muni bond market in India, the Seven-I framework has been used to capture the information flows. Salient features are highlighted below.

Based on the news flows, the most highlighted aspects are: Governance, Management and matters concerning the Issuer. The other aspects (Six-Is) are also important, but less significant, as per the news flows.
Governance: Participative democracy, ombudsman, good relations between the central, state and local governments and the right mix of centralization and decentralization.

Management: Professional CEO, CFO and staff, accountability, linkages between elected members and professional cadre, efficient management, transparency and disclosure in matters relating to accounting and finance, developing relationships with investors, market orientation of functioning.

\section{Seven-I Framework:}

Table 5: Summary of Seven-I Framework for Munis

\begin{tabular}{|l|l|}
\hline Aspect & Summary of Observations \\
\hline Issuer & $\begin{array}{l}\text { Identify and develop revenue streams, } \\
\text { diversify revenue base, inculcate financial } \\
\text { discipline, transparency and disclosure } \\
\text { standards in accounting and finance, develop } \\
\text { investor relations }\end{array}$ \\
\hline Investor & $\begin{array}{l}\text { Insurance comparies, pension funds, mutual } \\
\text { funds, banks, individuals and households }\end{array}$ \\
\hline Intermediaries & $\begin{array}{l}\text { Investment bankers, stock exchanges, stock } \\
\text { brokers, market makers, depositories, trustees } \\
\text { to bondholders, credit enhancers }\end{array}$ \\
\hline Instrument & $\begin{array}{l}\text { Plain vanilla coupon paying bonds, minimum } \\
\text { 3-yeartenor }\end{array}$ \\
\hline Innovation & $\begin{array}{l}\text { Pooled bonds, listing for liquidity, composite } \\
\text { issues of tax-free and taxable bonds, credit } \\
\text { enhancement }\end{array}$ \\
\hline Incentives & $\begin{array}{l}\text { Lower cost of funds on tax-free bonds, lower } \\
\text { cost of funds from listing (implied liquidity } \\
\text { from tra ding/market-making)tax incentives } \\
\text { forindividuals and household investors, } \\
\text { removal of caps on coupon interest rate, } \\
\text { market-determined coupon rate }\end{array}$ \\
\hline & $\begin{array}{l}\text { Gate-keeping function by intemal } \\
\text { management, accountants, auditors, credit } \\
\text { rating agencies, analysts to reduce } \\
\text { information asymmetry }\end{array}$ \\
\hline
\end{tabular}

Thus far, a total of 8 municipalities, through 25 issuances across 17 years, seem to have passed the primary market test, albeit through the private placement route. Most of the 8 municipalities would be better-prepared than the rest for gearing themselves for fresh issuances in the new scenario that enables listing and secondary market trading, under the new policy framework by SEBI and the Ministry of Finance, Government of India.

Some of the points missed out in the information flow could be crucial for the success of the Muni bond market in India. Firstly, tax incentives on infrastructure bonds issued by Indian infrastructure/infrastructure finance companies which granted a tax rebate on the principal investment (the erstwhile Section 80 CCF of the Indian Income Tax Act, 1961) could be reinstated, as they were hugely popular, even when the equity markets were in turmoil in the aftermath of the GFC of 2008. Secondly, in respect of institutional investors, the withholding tax on coupon interests could create friction in secondary market trades - this could be removed, since securities market transactions have a very good audit trail, and bringing transactions to tax would be an easy task for the tax 
collector in this information age.

The findings of this study match with those by Vaidya and Vaidya (2010), Chakrabarti (2014), and also by the Indian credit rating agencies but through an empirical framework, using the event study method. To conclude, it may be said that Governance, Management and the Issuer's perspectives have been identified as the most-highlighted aspects in this paper. However, SEBI and the Ministry of Finance also need to take note of the enveloping factors arising from the other Six Is, so that an enabling environment is created for a vibrant Muni bond market in India.

There is a need for follow-up studies based on a primary data survey, and also for empirical studies based on transactional data sets as and when the secondary markets take off in India

\section{NOTES}

1. Arup Roychoudhury, Municipal Bonds: FinMin Wants Cities Identified, Business Standard, Mumbai, dated January 5, 2015

2. Section 27A of the Insurance Act, 1938, as amended in 2000 and the IRDA Investment Regulations issued from time to time.

3. Bloomberg

4. Suresh Mathur, Advisor, New Delhi Municipal Council, February 12, 2015, New Delhi

5. Sunder Ram Korivi, at the India Regulatory Summit, panel on "Developing the Rupee Debt Market" at Mumbai on March 10, 2015

\section{REFERENCES}

1. Pierangela Samarati, Latanya Sweeney "Generalizing facts to Buettner, Theiss and David E. Wildasin (2003), The Dynamics of Municipal Fiscal Adjustment, Public Economics 0309007, Economics Working Paper at WUSTL

2. Chakrabarti, Manas (2014), Municipal Bond Rating in India: An Appraisal, International Journal of Informative and Futuristic Research, Vol.2, Issue 2, pp. 455-464

3. Hines, James R., Hilary Hoynes and Alan B. Krueger (2001), Another Look Whether a Rising Tide Lifts All Boats, Papers 454, Princeton, Department of Economics, Industrial Relations Section

4. Hines, James R. and Richard H. Thaler (1995), The Flypaper Effect, Journal of Economic Perspectives, Vol.9 (4), Fall, pp.217-226

5. Knight, Brian (2002), Endogenous Federal Grants and Crowd-Out of State Government Spending: Theory and Evidence from the Federal Highway Aid Programme, American Economic Review, Vol.92 (1), March, pp.7192

6. Megginson, William Leon (2005), The Financial Economics of Privatization), Oxford University Press, N.Y.

7. Mitra, Gautam and Leena Mitra (Ed.) (2011), The Handbook of News Analytics in Finance, John Wiley \& Sons, UK.

8. Partnoy, Frank (2003), Infectious Greed: How Deceit and Risk Corrupted the Financial Markets, Profile Books, London

9. Roemer, John E. and Joaquim Sylvestre (undated), The Flypaper Effect is Not an Anomaly, Department of Economics, California Davis
10. Temimi, Akram and Manfred Dix (2001), Federal Grants and the Flight to the Suburbs, The Quarterly Review of Economics, Elsevier, Vol.41 (4), pp.533-543

11. Timofeev Andrei (2002), Fiscal Decentralization and Soft Budget Constraints, Russia Working Paper Series, EERC Russia and CIS

12. Vaidya, Chetan and Hitesh Vaidya (2010), Market Based Funding of Urban Infrastructure in India, published in Building from the Bottom, Academic Foundation, downloaded from http://indiancities.berkeley.edu/speaker_content/docs/Vai dya-MARKETBASED_FINANCING_URBAN INFRASTRUCTURE INDIA.DOC, May 23, 2015, 10.58 PM IST

13. Wang Janbo, Chunchi Wu and Frank X. Zhang (2008), Liquidity, Default, Taxes and Yields on Municipal Bonds, Journal of Banking and Finance, Vol.32, Issue 6, pp. 1133 to 1149

\section{AUTHORS PROFILE}

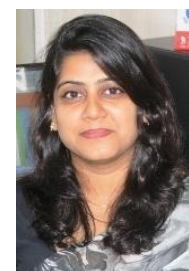

Pali Gaur is a research scholar at Symbiosis International University, Pune. She is MBA finance and as a finance professional handled diverse work profiles in academics as well as corporate. Over the years, she has developed strong analytical and problem solving ability, in different areas of finance. She has been associated with reputed institutions like ISBM Pune, TASMAC London and Symbiosis Pune as a faculty finance. Her interest areas in research encompass municipal bonds, green bonds with the sustainability aspect attached to it and different modes of funding infrastructure projects in India. Email: pali.gaur@gmail.com

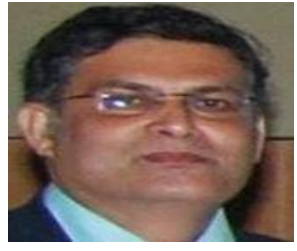

Sunder Ram Korivi, PhD., is Senior consultant, DEA-NIFM Research cell at National Institute of Financial Management. Prof. Sunder Ram Korivi is an MA (Economics $\&$ Political Science) and PhD (Business Policy $\&$ Administration) from the University of Mumbai. He is a CA Rank-holder (Nov.1989, All-India 7th) and Fellow of the Institute of Chartered Accountants of India. Additionally, he is also an Associate member of the Institute of Cost \& Management Accountants of India and the Insurance Institute of India. He was a full-time faculty member at SP Jain Institute of Management. His interests are in the fields of Financial Reporting, Financial Institutions \& Markets and Fixed Income Securities. He has won several Best Teacher awards. 